\title{
KARAKTERISTIK TINGKAT KETAHANAN PANGAN RUMAH TANGGA PETANI BERBASIS AGROEKOSISTEM LAHAN SAWAH IRIGASI DI PROVINSI BALI
}

\author{
Suharyanto \\ Balai Pengkajian Teknologi Pertanian (BPTP) Bali \\ Jl. Bypass Ngurah Rai, Pesanggaran, Denpasar 80222 \\ E-mail : suharyanto.bali@gmail.com
}

\begin{abstract}
Household food security level essentially is the ability of households meet food sufficiency. These capabilities are greatly influenced by many complex factors, but generally associated with changes in behavioral aspects of food production, consumption and allocation of households resources. The purpose of this study was to analyze the level of household food security based on low land rice irrigated. The study was conducted in three districts of rice production center in the province of Bali in 2012, i.e. Tabanan district, Gianyar and Buleleng. Data collection was conducted through interviews with 216 respondents. Household food security was measured by cross classification of the share of food expenditure and consumption of energy. The results of the analysis showed $58.33 \%$ of households have a lower share of food expenditure and $41.67 \%$ household have higher share of food expenditure. In aggregate $86.57 \%$ of farm households is quite in consuming energy and $13.43 \%$ is less in energy consume. The level of household food security of farmers in the aggregate $49.07 \%$ of the household were categorized as secure, $37.9 \%$ as vulnerable, $8.79 \%$ as insufficient, and $4.17 \%$ as insecure. There is a correlation between the level of household food security with age of housewife, level of education, farm size and household income.
\end{abstract}

Keywords :food security, household, farmer, lowland rice

\begin{abstract}
Abstrak: Ketahanan pangan di tingkat rumah tangga hakekatnya menunjukkan kemampuan rumah tangga memenuhi kecukupan pangan. Kemampuan tersebut dipengaruhi banyak faktor yang sangat kompleks, tetapi secara umum terkait dengan perubahan aspek perilaku produksi pangan, konsumsi dan alokasi sumberdaya dalam rumah tangga. Tujuan penelitian ini untuk menganalisis tingkat ketahanan pangan rumah tangga petani berbasis agroekosistem lahan sawah irigasi. Penelitian dilakukan di tiga kabupaten sentra produksi padi sawah di Provinsi Bali tahun 2012, Kabupaten Tabanan, Gianyar dan Buleleng. Pengumpulan data dilakukan melalui wawancara terhadap 216 responden. Ketahanan pangan rumah tangga diukur menggunakan klasifikasi silang pangsa pengeluaran pangan dan kecukupan energi. Hasil analisis menunjukan 58,33 persen rumah tangga memiliki pangsa pengeluaran pangan rendah dan 41,67 persen rumah tangga pangsa pengeluarannya tinggi. Secara agregat 86,57 persen rumah tangga petani tergolong cukup dalam mengkonsumsi energi dan 13,43 persen rumah tangga tergolong kurang mengkonsumsi energi. Tingkat ketahanan pangan rumah tangga petani secara agregat berturut-turut 49,07 persen tergolong tahan pangan, 37,96 persen rumah tangga tergolong rentan pangan, 8,80 persen tergolong kurang pangan dan 4,17 persen rumah tangga petani tergolong rawan pangan. Terdapat korelasi antara tingkat ketahanan pangan rumah tangga dengan umur ibu rumah tangga, tingkat pendidikan, jumlah anggota rumah tangga dan pendapatan rumah tangga.
\end{abstract}

Kata kunci : ketahanan pangan, rumah tangga, petani, padi sawah 


\section{PENDAHULUAN}

Di Indonesia, pengertian ketahanan pangan telah ditetapkan dalam Undang-Undang Nomor 18 Tahun 2012 tentang pangan. Dalam undangundang tersebut yang dimaksud dengan ketahanan pangan adalah kondisi terpenuhinya pangan bagi negara sampai dengan perseorangan, yang tercermin dari tersedianya pangan yang cukup, baik jumlah maupun mutunya, aman, beragam, bergizi, merata, dan terjangkau serta tidak bertentangan dengan agama, keyakinan, dan budaya masyarakat, untuk dapat hidup sehat, aktif, dan produktif secara berkelanjutan.

Ketahanan pangan rumah tangga berhubungan dengan kemampuan rumah tangga tersebut untuk memenuhi kebutuhan seluruh anggotanya (Usfar 2002). Hal ini menyiratkan akses fisik dan ekonomi terhadap pangan yang cukup dalam kuantitas dan kualitas gizi, aman, dan dapat diterima oleh budaya setempat untuk memenuhi kebutuhan tiap anggota keluarga. Akses rumah tangga terhadap pangan merupakan strategi-strategi untuk mendapatkan makanan dari berbagai sumber. Makanan bagi suatu rumah tangga dapat berasal dari beberapa sumber antara lain: dengan memproduksi sendiri, membeli, atau berasal dari pemberian. Akses individu dalam menjangkau kebutuhan pangan sangat dipengaruhi oleh daya beli, tingkat pendapatan, harga pangan, proses distribusi pangan, kelembagaan ditingkat lokal dan faktor sosial lainnya.

Ketahanan pangan di tingkat rumah tangga hakekatnya menunjukkan kemampuan rumah tangga memenuhi kecukupan pangan. Kemampuan tersebut dipengaruhi banyak faktor yang sangat kompleks, tetapi secara umum terkait dengan perubahan aspek perilaku produksi pangan, konsumsi dan alokasi sumberdaya dalam rumah tangga. Purwantini et al (2005) menyatakan bahwa walaupun di tingkat regional status ketahanan pangan wilayah tergolong tahan pangan terjamin, namun tidak cukup menjamin ketahanan pangan di tingkat rumah tangga.

Peningkatan ketahanan pangan diarahkan pada kemandirian masyarakat/petani yang berbasis sumberdaya lokal yang dilakukan melalui program peningkatan produksi pangan; menjaga ketersediaan pangan yang cukup, aman dan halal di setiap daerah setiap saat; dan antisipasi agar tidak terjadi kerawanan pangan. Upaya untuk menuju pada peningkatan kesejahteraan petani secara operasional dapat dilakukan melalui pemberdayaan penyuluhan, pendampingan, penjaminan usaha, perlindungan harga gabah, kebijakan proteksi dan promosi.Hal tersebut dapat dimengerti mengingat sebagian besar petani di Indonesia untuk komoditas beras masih tergolong petani subsisten dalam artian berperan sebagai produsen sekaligus konsumen beras. Dengan demikian maka jumlah beras yang dijual ke pasar akan sangat bergantung pada surplus konsumsi rumah tangga dan harga beras serta harga barang lain yang diperlukan petani dari industri lain (Darwanto, 2005).Tulisan ini bertujuan untuk mengetahui bagaimana tingkat ketahanan pangan rumah tangga petani padi sawah berdasarkan indikator pangsa pengeluaran pangan dan kecukupan konsumsi energy rumah tangga.

\section{METODE PENELITIAN}

Desain penelitian adalah riset eksploratori yaitu suatu penelitian yang dimaksudkan untuk mendapatkan gambaran atau identifikasi mengenai ketahanan pangan rumah tangga petani padi sawah di Provinsi Bali. Dalam eksploratori diperoleh data kualitatif yang sifatnya mendalam dan kontekstual serta data kuantitatif. Metode yang digunakan adalah survei yaitu penelaahan informasi dari berbagai dimensi pada objek penelitian. Metode pendekatannya menggunakan cross sectional study yaitu suatu penelitian yang dilakukan hanya pada satu waktu tertentu tanpa melakukan suatu perlakuan pada objek sehingga menghasilkan gambaran situasi pada saat tertentu.

Penelitian dilaksanakan di Kabupaten Buleleng, Gianyar dan Tabanan dengan pertimbangan bahwa ketiga kabupaten tersebut merupakan sentra produksi padi sawah di Provinsi Bali dan juga memiliki populasi rumah tangga tani relatif lebih tinggi dibandingkan kabupaten lainnya. Penarikan sampel dengan menggunakan metode acak sederhana dimana setiap populasi memiliki peluang yang sama untuk dijadikan sebagai sampel. Jumlah responden yang digunakan sebanyak 216 rumah tangga petani yang 
terdistribusi di Kabupaten Buleleng 72 responden, Gianyar 66 responden dan Tabanan 78 responden. Data konsumsi pangan diperoleh dengan menggunakan metode recall selama satu minggu dan dikonversi ke dalam satuan konsumsi energi dan zat gizi Iainnya dengan menggunakan Daftar Komposisi Bahan Makanan (DKBM) serta recall pengeluaran pangan dan non pangan.

Untuk mengukur derajat ketahanan pangan tingkat rumah tangga, digunakan klasifikasi silang dua indikator ketahanan pangan, yaitu pangsa pengeluaran pangan dan kecukupan konsumsi energi (kkal) (Jonsson and Toole, 1991 dalam Maxwell and Frankenberger, 1992) seperti yang ditunjukkan pada Tabel 1. Pada tabel tersebut terlihat bahwa batasan 80 persen dari konsumsi energi (per unit ekuivalen dewasa) akan dikombinasikan dengan pangsa pengeluaran pangan $>60$ persen dari total pengelaran rumah tangga, sehingga dihasilkan kriteria : (1) Rumah tangga tahan pangan yaitu bila proporsi pengeluaran pangan rendah (kurang dari 60 persen pengeluaran rumah tangga) dan cukup mengkonsumsi energi (> 80 persen dari syarat kecukupan energi), (2) Rumah tangga rentan pangan yaitu bila proporsi pengeluaran pangan tinggi (lebih dari 60 persen pengeluaran rumah tangga) dan cukup mengkonsumsi energi (> 80 persen dari syarat kecukupan energi), (3) Rumah tangga kurang pangan yaitu bila proporsi pengeluaran pangan tinggi (lebih dari 60 persen pengeluaran rumah tangga) dan kurang mengkonsumsi energi $(\leq 80$ persen dari syarat kecukupan energi), (4) Rumah tangga rawan pangan yaitu bila proporsi pengeluaran pangan tinggi dan tingkat konsumsi energinya kurang.

Pada penelitian ini yang dimaksud dengan pangsa pegeluaran pangan adalah rasio pengeluaran untuk belanja pangan dan pengeluaran total rumah tangga selama satu bulan. Perhitungan pangsa pengeluaran pangan $(P F)$ pada berbagai kondisi, yaitu dengan menggunakan formula berikut :

$$
P F t=\frac{P P t}{T P t} \times 100 \%
$$

Tingkat kecukupan konsumsi energi rata-rata per kapita tidak menggambarkan tingkat konsumsi riil, karena umur penduduk mempengaruhi tingkat kecukupan energi. Pada penelitian ini tingkat kecukupan energi didekati dengan konsumsi energi per ekuivalen orang dewasa (KE) mengacu pada Rachman et al., (2002) dan Purwantini et al (2005). KE dihitung berdasarkan konsumsi riil rumah tangga dibagi Jumlah Unit Ekuivalen orang Dewasa (JUED). Untuk menghitung tingkat pencapaian konsumsi energi standar normatif diperoleh dengan membandingkan standar kecukupan energi orang dewasa standar normatif. Apabila tingkat pencapaian konsumsi energy kurang dari 100 persen, artinya belum mencapai tingkat kecukupan yang sesuai standar normatif. Penghitungan konsumsi energi menggunakan rumus sebagai berikut (Purwantini et al (2005) dan Rachman et al., (2002) :

Tabel 1. Indikator Ketahanan Pangan dengan Menggunakan Klasifikasi Silang Kecukupan Energi dan Pangsa Pengeluaran Pangan

\begin{tabular}{ccc}
\hline \multirow{2}{*}{$\begin{array}{c}\text { Konsumsi energi per ekuivalen } \\
\text { dewasa }\end{array}$} & \multicolumn{2}{c}{ Pangsa Pengeluaran Pangan } \\
\cline { 2 - 3 } Cukup & $\begin{array}{c}\text { Rendah } \\
\text { Tinggi }\end{array}$ & $\begin{array}{c}(<60 \% \text { pengeluaran total }) \\
(\geq 60 \% \text { pengeluaran total })\end{array}$ \\
Kurang & Tahan Pangan & Rentan Pangan \\
$(\leq 80 \%$ syarat kecukupan energi) & Kurang Tahan & Rawan \\
\hline
\end{tabular}

Sumber: Jonsson dan Toole (1991) dalam Maxwell dan Frankenberger. (1992) 
Konsumsi Energi Riil Rumah Tangga (KErt) :

Kert $=\frac{\text { BPj }}{100} \times \frac{\text { BDD }}{100} \times$ KGij ....... (2)

Konsumsi Energi per Ekuivalen Orang Dewasa (KED) :

$$
\mathrm{KED}=\frac{\mathrm{KErt}}{\mathrm{JUED}} \ldots \ldots \ldots \ldots
$$

Persentase Kecukupan Energi (PKE) :

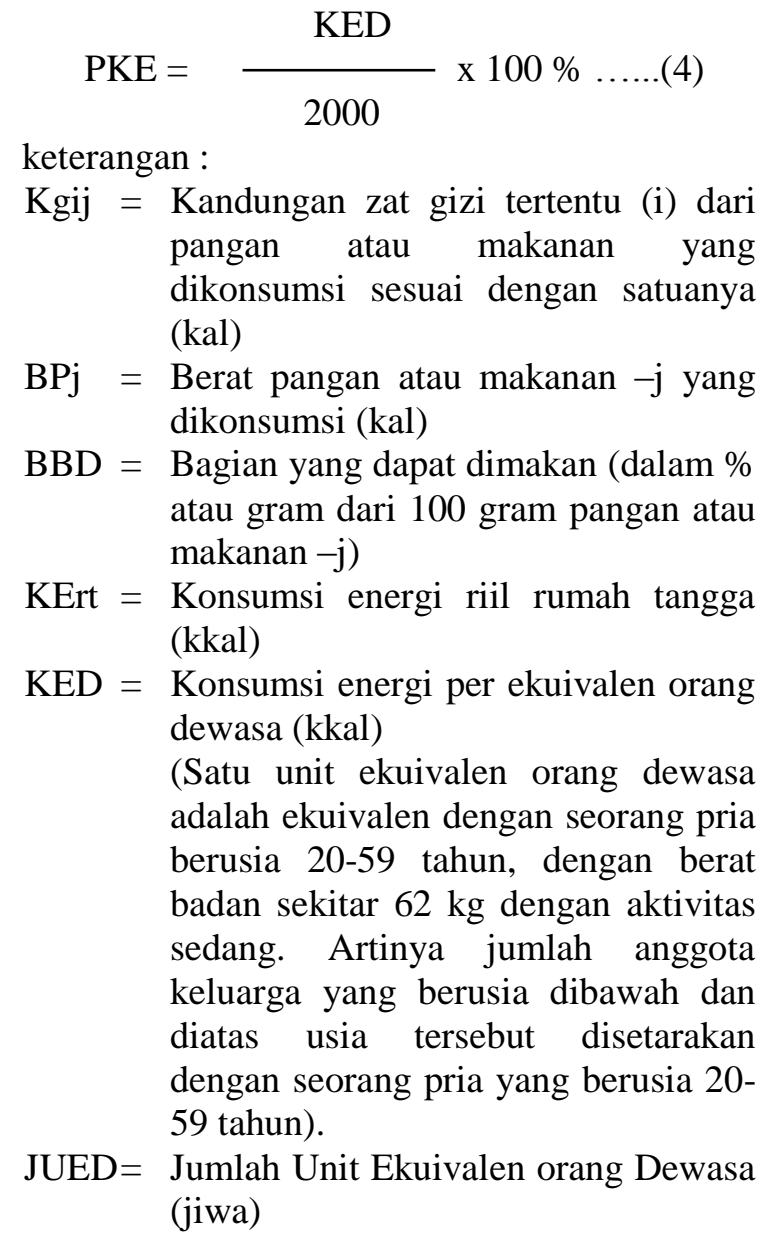

\section{HASIL DAN PEMBAHASAN}

\section{Tingkat Ketahanan Pangan Rumah tangga} Petani

Kebutuhan rumah tangga secara garis besar dapat dikelompokkan ke dalam dua kategori, yaitu kebutuhan akan pangan dan non pangan. Dengan demikian, pada tingkatan pendapatan tertentu rumah tangga akan mengalokasikan pendapatannya untuk memenuhi kedua kebutuhan. Jumlah pendapatan yang dibelanjakan untuk pangan oleh suatu rumah tangga dapat digunakan sebagai indikator tingkat kesejahteran rumah tangga tersebut. Semakin tinggi pangsa pengeluaran pangan, berarti semakin kurang sejahtera rumah tangga tersebut. Sebaliknya semakin kecil pangsa pengeluaran pangan maka rumah tangga tersebut kesejahteraannya semakin meningkat. Hasil penelitian Tanziha dan Herdiana (2009) mengungkapkan bahwa pengaruh langsung terbesar terhadap ketahanan pangan rumah tangga adalah pengeluaran rumah tangga sedangkan secara tak langsung dipengaruhi oleh jumlah anggota rumah tangga.

Rata-rata jumlah pengeluaran rumah tangga petani padi sawah di lokasi penelitian sebesar Rp 2.032.213/bulan. Proporsi pengeluaran rumah tangga untuk pangan sebesar 49.11 persen sedangkan non pangan sebesar 50.89 persen. Dengan demikian dapat dinyatakan bahwa secara rata-rata rumah tangga petani padi sawah di Provinsi Bali mempunyai proporsi pengeluaran pangan kurang dari $60 \%$, atau rumah tangga mempunyai katagori pangsa pengeluaran pangan rendah (Jonsson dan Toole, 1991 dalam Maxwell et al., 2000). Hasil ini juga berbeda dengan temuan Amaliayah dan Handayani (2011) yang mendapatkan proporsi pengeluaran pangan lebih besar dibandingkan non pangan pada petani padi sawah di Kabupaten Klaten yang berimplikasi bahwa rumah tangga memiliki tingkat kesejahteraan yang masih rendah.

Struktur pengeluaran rumah tangga merupakan salah satu indikator tingkat kesejahteraan rumah tangga. Dalam hal ini rumah tangga dengan pangsa pengeluaran pangan tinggi tergolong rumah tangga dengan tingkat kesejahteraan relatif rendah dibanding rumah tangga dengan proporsi pengeluaran pangan yang rendah (Ilham dan Sinaga, 2007; Purwaningsih et al, 2010). Meningkatnya kesejahteraan akan meningkatkan konsumsi pangan karena daya beli terhadap pangan makin meningkat. Dengan kata lain menurunnya pangsa pengeluaran pangan akan meningkatkan ketahanan pangan.

Keragaan pangsa kecukupan energi rumah tangga petani padi sawah di Provinsi Bali dapat dilihat pada Gambar 1. Secara agregat rumah tangga petani padi sawah di Provinsi Bali tergolong cukup dalam 
mengkonsumsi energi, dimana 187 rumah tangga (86,57 persen) mengkonsumsi energi diatas 80 persen dan sebanyak 29 rumah tangga $(13,43$ persen $)$ yang tergolong dalam kriteria kurang mengkonsumsi energi (dibawah 80 persen). Pada Gambar 1. terlihat bahwa secara keseluruhan pangsa pengeluaran pangan rumah tangga petani padi sawah di Provinsi Bali tergolong rendah dimana 58,33 persen tergolong pangsa pengeluaran pangan rendah ( $<60$ persen) dan 41,67 persen rumah tangga yang memiliki pangsa pengeluaran diatas 60 persen.
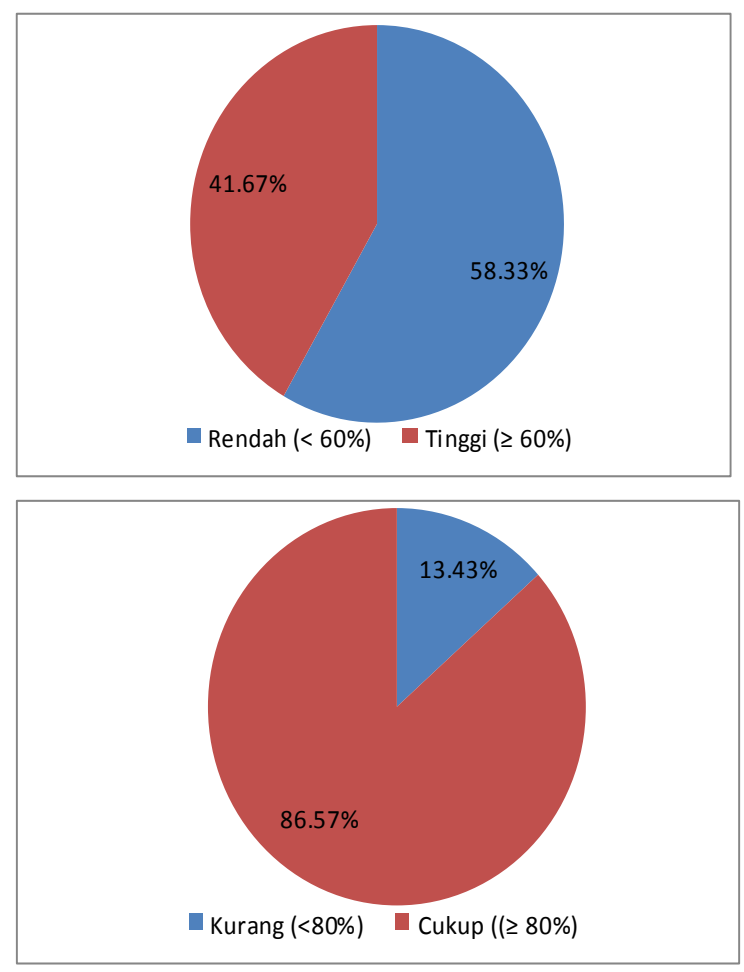

Gambar 1. Pangsa Pengeluaran Pangan dan Pangsa Kecukupan Energi Rumah Tangga Petani Padi Sawah di Provinsi Bali

Pada Gambar 2. terlihat bahwa distribusi rumah tangga petani padi sawah di Provinsi Bali secara agregat terdiri dari 106 rumah tangga (49,07 persen) tergolong tahan pangan, 82 rumah tangga petani (37,96 persen) tergolong rentan pangan, 19 rumah tangga petani $(8,80$ persen) tergolong kurang pangan dan sebanyak 9 rumah tangga (4,17 persen) petani dijumpai tergolong rawan pangan. Rumah tangga rentan pangan adalah rumah tangga yang mempunyai pangsa pengeluaran tinggi namun cukup mengkonsumsi
energi.Pangsa pengeluaran pangan tinggi berarti lebih dari $60 \%$ bagian pendapatan dibelanjakan untuk pangan. Kondisi ini mengindikasikan rendahnya pendapatan yang diterima oleh kelompok rumah tangga tersebut. Secara umum sumber pendapatan utama dari sebagian besar responden adalah usahatani padi, maka upaya peningkatan produksi dalam rangka peningkatan pendapatan petani perlu terus diupayakan. Dengan keterbatasan pendapatan yang dimiliki, rumah tangga rentan pangan dapat mengalokasikan pengeluaran pangannya sehingga dapat memenuhi kecukupan energi. Pada kelompok rumah tangga ini, pendapatan merupakan faktor utama untuk mencapai ketahanan pangan. Sebagaimana dinyatakan Ariani dan Rahman (2003) pada kelompok rumah tangga rentan pangan, hal utama yang perlu dilakukan adalah peningkatan akses terhadap pangan melalui peningkatan pendapatan diikuti dengan peningkatan pengetahuan pangan dan gizi.

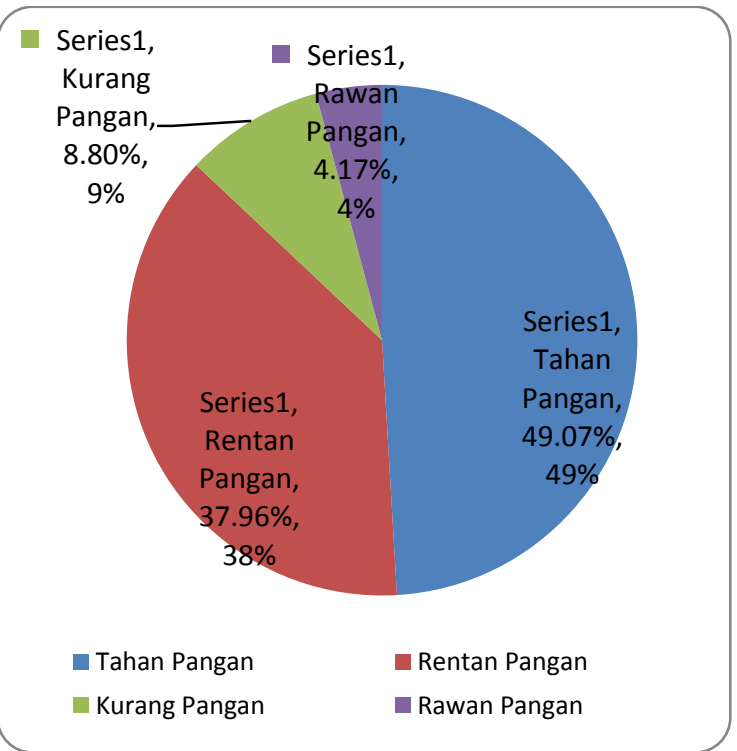

Gambar 2. Persentase Tingkat Ketahanan Pangan Rumah tangga

\section{Tingkat Ketahanan Pangan Menurut Karakteristik Rumah tangga}

Tingkat ketahanan pangan rumah tangga petani padi sawah menurut kelompok umur disajikan pada Tabel 2. Pada Tabel 2. terlihat bahwa tingkat ketahanan rumah tangga yang termasuk kriteria tahan pangan tertinggi berturut-turut pada kelompok umur 30 -49 tahun (25.00 persen), umur 50 - 64 ( 21.76 persen), umur 
20-29 tahun (1.39 persen) dan kelompok umur diatas 65 tahun tidak dijumpai ketahanan pangan dengan kriteria tahan pangan. Sedangkan rumah tangga yang tergolong dalam kriteria rawan pangan berturut-turut tertinggi ditemukan pada kisaran umur 50 -64 tahun (2.78 persen), umur diatas 65 tahun (1.39 persen), umur $30-49$ tahun (0.93 persen) dan pada kelompok umur $20 \quad-29$ tahun tidak dijumpai rumah tangga dengan krteria rawan pangan.Berdasarkan temuan tersebut selanjutnya dapat dinyatakan bahwa pada kelompok usia $>30-\leq 49$ tahun dan $>49-\leq 64$ tahun, tingkat ketahanan pangan dominan pada kategori tahan pangan masing-masing 25\% dan $21.76 \%$ dibandingkan kategori rentan, kurang dan rawan pangan. Sedangkan pada kelompok umur $\geq 65$ tahun dominan pada kategori rentan dan kurang pangan bahkan tidak dijumpai tingkat ketahanan pangan dengan kategori tahan pangan. Dengan kata lain ketahanan pangan rumah tangga akan semakin meningkat dengan semakin bertambahnya usia seseorang sampai pada batasan tertentu dan selanjutnya akan turun pada tingkatan ketahanan pangan tertentu. Secara alamiah dengan bertambahnya umur seseorang maka akan semakin meningkatkan wawasan dan pengalamannya sehingga berdasarkan hal tersebut ibu rumah tangga secara rasional dapat mengalokasikan pendapatan rumah tangganya untuk pemenuhan gizi keluarga dalam rangka peningkatan ketahanan pangan rumah tangga.

Distribusi tingkat ketahanan rumah tangga menurut tingkat pendidikan disajikan pada Tabel 3. Pada Tabel 3 terlihat bahwa pendidikan ibu rumahtagga secara keseluruhan didominasi pendidikan dasar (SD) dan menengah (SMP) masing masing sebesar 33,80 persen dan 31,94 persen dan 26,85 persen ibu rumah tangga yang berpendidikan SMA. Berdasarkan tingkat ketahananan pangan rumah tangga, rumah tangga tahan pangan didominasi berturut-turut oleh rumah tangga dengan tingkat pendidikan ibu rumah tangga tamat SMA (18,06 persen), tamat SMP (16.20 persen), tamat SD (12,04 persen) dan tidak tamat SD (1.85 persen). Sebaliknya rumah tangga dengan kategori rawan pangan didominasi berturut-turut oleh tingkat pendidikan tamat SD (2.31 persen), tidak tamat tamat SD (1,39 persen), tamat SMP (0.93 persen) dan tamat SMA (0,46 persen). Tingkat pendidikan ibu rumah tangga akan berkaitan dengan tingkat pengetahuan terhadap bahan pangan yang juga sangat mempengaruhi pola konsumsi rumah tangga. Apabila suatu rumah tangga memiliki pengetahuan yang cukup mengenai bahan pangan yang sehat, bergizi, dan aman untuk dikonsumsi. Maka rumah tangga tersebut tentunya akan lebih rasional dalam menentukan pola konsumsi rumah tangganya.

Tabel 2. Tingkat Ketahanan Pangan Rumah Tangga Petani Padi Sawah Menurut Kelompok Umur Ibu Rumah tangga

\begin{tabular}{cccccc}
\hline $\begin{array}{c}\text { Kelompok Umur } \\
\text { (thn) }\end{array}$ & \multicolumn{4}{c}{ Tingkat Ketahanan Pangan } & \multirow{2}{*}{ Total } \\
\cline { 2 - 5 } $20-\leq 30$ & Tahan Pangan & Rentan Pangan & Kurang pangan & Rawan Pangan & \\
& $(1.39)$ & $(0.46)$ & 1 & 0 & 5 \\
$>30-\leq 49$ & 54 & 41 & $(0.46)$ & $(0.00)$ & $(\mathbf{2 . 3 1 )}$ \\
& $(25.00)$ & $(18.98)$ & $(2.78)$ & $(0.93)$ & $(\mathbf{4 7 . 6 9 )}$ \\
$>49-\leq 64$ & 47 & 34 & 7 & 6 & 94 \\
& $(21.76)$ & $(15.74)$ & $(3.24)$ & $(2.78)$ & $\mathbf{( 4 3 . 5 2 )}$ \\
$\geq 65$ & 0 & 6 & 5 & 3 & 14 \\
& $(0.00)$ & $(2.78)$ & $(2.31)$ & $(1.39)$ & $\mathbf{( 6 . 4 8 )}$ \\
\hline \multirow{2}{*}{ Jumlah } & 104 & 82 & 19 & 11 & 216 \\
& $(48.15)$ & $(37.96)$ & $(8.79)$ & $(5.10)$ & $\mathbf{( 1 0 0 . 0 0 )}$ \\
\hline
\end{tabular}

Sumber : Analisis data Primer, 2012 (diolah).

Keterangan :

* angka dalam kurung adalah persentase dari masing-masing tingkat ketahanan pangan

* angka dalam kurung dan dicetak tebal adalah persentase sampel per kelompok umur 
Suharyanto: Karakteristik tingkat ketahanan pangan rumah tangga ...

Tabel 3. Tingkat Ketahanan Pangan Rumah tangga Petani Padi Sawah Menurut Tingkat Pendidikan Ibu Rumah tangga

\begin{tabular}{|c|c|c|c|c|c|}
\hline \multirow{2}{*}{$\begin{array}{c}\text { Tingkat } \\
\text { Pendidikan }\end{array}$} & \multicolumn{4}{|c|}{ Tingkat Ketahanan Pangan } & \multirow{2}{*}{ Total } \\
\hline & Tahan Pangan & Rentan Pangan & Kurang pangan & Rawan Pangan & \\
\hline \multirow[t]{2}{*}{ Tidak Tamat SD } & 4 & 7 & 2 & 3 & 16 \\
\hline & $(1.85)$ & $(3.24)$ & $(0.93)$ & $(1.39)$ & (7.41) \\
\hline \multirow[t]{2}{*}{ Tamat SD } & 26 & 31 & 11 & 5 & 73 \\
\hline & $(12.04)$ & $(14.35)$ & $(5.09)$ & $(2.31)$ & (33.80) \\
\hline \multirow[t]{2}{*}{ Tamat SMP } & 35 & 28 & 4 & 2 & 69 \\
\hline & $(16.20)$ & $(12.96)$ & $(1.85)$ & $(0.93)$ & (31.94) \\
\hline \multirow[t]{2}{*}{$\geq$ SMA } & 39 & 16 & 2 & 1 & 58 \\
\hline & $(18.06)$ & $(7.41)$ & $0.93)$ & $(0.46)$ & $(26.85)$ \\
\hline \multirow{2}{*}{ Jumlah } & 104 & 82 & 19 & 11 & 216 \\
\hline & $(48.15)$ & (37.96) & $(8.80)$ & (5.09) & $(100.00)$ \\
\hline
\end{tabular}

Sumber : Analisis data Primer, 2012 (diolah).

Keterangan :

* angka dalam kurung adalah persentase dari masing-masing tingkat ketahanan pangan

* angka dalam kurung dan dicetak tebal adalah persentase sampel per tingkat pendidikan

Tabel 4. Tingkat Ketahanan Pangan Rumah tangga Petani Padi Sawah Menurut Jumlah Anggota Rumah tangga

\begin{tabular}{cccccc}
\hline Jumlah Anggota & \multicolumn{4}{c}{ Tingkat Ketahanan Pangan } & \multirow{2}{*}{ Total } \\
\cline { 2 - 5 } Rumahtangga & Tahan Pangan & Rentan Pangan & Kurang pangan & Rawan Pangan & \\
\hline$\leq 4$ & 64 & 35 & 8 & 4 & 111 \\
& $(29.63)$ & $(16.20)$ & $(3.70)$ & $(1.85)$ & $\mathbf{( 4 8 . 1 5 )}$ \\
$>4$ & 40 & 47 & 11 & 7 & 105 \\
& $(18.52)$ & $(21.76)$ & $(5.09)$ & $(3.24)$ & $\mathbf{( 4 8 . 6 1 )}$ \\
\hline \multirow{2}{*}{ Jumlah } & 104 & 82 & 19 & 11 & 216 \\
& $(48.15)$ & $(37.96)$ & $(8.79)$ & $(5.09)$ & $\mathbf{( 1 0 0 . 0 0 )}$ \\
\hline
\end{tabular}

Sumber : Analisis data Primer, 2012 (diolah).

Keterangan :

* angka dalam kurung adalah persentase dari masing-masing tingkat ketahanan pangan

* angka dalam kurung dan dicetak tebal adalah persentase sampel dari jumlah anggota RT

Ukuran rumah tangga atau jumlah anggota rumah tangga merupakan salah satu faktor yang cukup berperan terhadap tingkat ketahanan rumah tangga.Pada Tabel 4 disajikan tingkat ketahanan rumah tangga petani padi sawah menurut jumlah anggota rumah tangga. Dengan asumsi jumah anggota rumah tangga rendah $(\leq 4$ jiwa) dan jumlah angota rumah tangga tinggi ( $>4$ jiwa) terlihat bahwa rumah tangga tahan pangan lebih tinggi terdapat pada rumah tangga dengan jumlah anggota rumah tangganya $\leq 4$ jiwa $(29,63$ persen $)$ dibandingkan dengan rumah tangga dengan $>4$ jiwa $(18,52)$. Sedangkan rumah tangga dengan kriteria rawan pangan jumlah anggota rumah tangga $>4(3,24$ persen $)$ lebih tinggi dibandingkan dengan jumlah anggota rumah tangga $\leq 4$ jiwa (1,85 persen). Hal ini dapat dijelaskan bahwa dengan tingkat pendapatan tertentu semakin besar jumlah anggota rumah tangga semakin rendah alokasi konsumsi per kapita yang diperoleh setiap anggota rumah tangga, dengan demikian akan semakin rendah ketahanan pangan rumah tangga yang bersangkutan.

Distribusi tingkat ketahanan pangan rumah tangga petani padi sawah menurut kelompok pendapatan total rumah tangga disajikan pada Tabel 5. Pada tabel tersebut terlihat bahwa tingkat ketahanan pangan dengan kategori tahan pangan berturut-turut meningkat dari kelompok pendapatan rendah sampai tinggi dimana pada kelompok pendapatan > Rp.3.000.000.000 (18,98 persen), kelompok pendapatan Rp. 2.000.000 3.000 .000 (18,06 persen) dan kelompok 
Tabel 5. Distribusi Tingkat Ketahanan Pangan Rumah Tangga Petani Padi Sawah Menurut Kelompok Total Pendapatan Rumah tangga

\begin{tabular}{|c|c|c|c|c|c|}
\hline \multirow{2}{*}{$\begin{array}{l}\text { Kelompok Pendapatan } \\
(\mathrm{Rp} / \mathrm{B} \ln )\end{array}$} & \multicolumn{4}{|c|}{ Tingkat Ketahanan Pangan } & \multirow{2}{*}{ Total } \\
\hline & Tahan Pangan & Rentan Pangan & Kurang pangan & Rawan Pangan & \\
\hline \multirow[t]{2}{*}{$<2.000 .000$} & 24 & 44 & 16 & 8 & 92 \\
\hline & (11.11) & $(20.37)$ & $(7.41)$ & $(3.70)$ & $(42.59)$ \\
\hline \multirow[t]{2}{*}{$>2.000 .000-\leq 3.000 .000$} & 39 & 29 & 3 & 3 & 74 \\
\hline & $(18.06)$ & $(13.43)$ & $(1.39)$ & $(1.39)$ & $(42.59)$ \\
\hline \multirow[t]{2}{*}{$>3.000 .000$} & 41 & 9 & 0 & 0 & 50 \\
\hline & $(18.98)$ & $(4.17)$ & $(0.00)$ & $(0.00)$ & $(\mathbf{1 4 . 8 1 )}$ \\
\hline \multirow{2}{*}{ Jumlah } & 104 & 82 & 19 & 11 & 216 \\
\hline & (48.15) & (37.96) & (8.79) & (5.09) & $(100.00)$ \\
\hline
\end{tabular}

Sumber : Analisis data primer, 2011 (diolah).

Keterangan :

* angka dalam kurung adalah persentase dari masing-masing tingkat ketahanan pangan

* angka dalam kurung dan dicetak tebal adalah persentase sampel dari kelompok pendapatan

Tabel 6. Tingkat Ketahanan Pangan Rumah tangga Petani Padi Sawah Menurut Kabupaten di Provinsi Bali

\begin{tabular}{lccccc}
\hline \multirow{2}{*}{ Kabupaten } & \multicolumn{4}{c}{ Tingkat Ketahanan Pangan } & \multirow{2}{*}{ Total } \\
\cline { 2 - 5 } & Tahan Pangan & Rentan Pangan & Kurang pangan & Rawan Pangan & \\
\hline Buleleng & 31 & 29 & 8 & 4 & 72 \\
Gianyar & $(14.35)$ & $(13.43)$ & $(3.70)$ & $(1.85)$ & $\mathbf{( 3 3 . 3 3 )}$ \\
& 37 & 23 & 4 & 2 & 66 \\
Tabanan & $(17.13)$ & $(10.65)$ & $(1.85)$ & $(0.93)$ & $\mathbf{( 3 0 . 5 6 )}$ \\
& 38 & 30 & 7 & 3 & 78 \\
& $(17.59)$ & $(13.89)$ & $(3.24)$ & $(1.39)$ & $\mathbf{( 3 6 . 1 1 )}$ \\
\hline \multirow{2}{*}{ Jumlah } & 106 & 82 & 19 & 9 & 216 \\
& $(49.07)$ & $(37.97)$ & $(8.79)$ & $(4.17)$ & $\mathbf{( 1 0 0 . 0 0 )}$ \\
\hline
\end{tabular}

Sumber : Analisis data primer, 2011 (diolah).

Keterangan :

* angka dalam kurung adalah persentase dari masing-masing tingkat ketahanan pangan

* angka dalam kurung dan dicetak tebal adalah persentase sampel dari kelompok pendapatan

pendapatan < Rp. 2.000.000,- (11,11 persen). Sedangkan pada kategori rumah tangga rawan pangan justru sebaliknya, kelompok pendapatan < Rp 2.000.000 (3,70 persen), kelompok pendapatan Rp.2.000.000 Rp.3.000.000 (1,39 persen) dan kelompok pendapatan > Rp.3.000.000 (0,00 persen).

\section{Tingkat Ketahanan Pangan Menurut Kabupaten}

Distribusi tingkat ketahanan rumah tangga petani padi sawah menurut wilayah kabupaten disajikan pada Tabel 6. Pada Tabel 6 terlihat bahwa kecenderungan proporsi tingkat ketahanan rumah tangga petani padi sawah di ketiga kabupaten relatif tidak jauh berbeda, dimana tingkat ketahanan pangan rumah tangga berturut-turut tertinggi adalah tahan pangan, rentan pangan, kurang pangan dan rawan pangan. Kriteria tahan pangan tertinggi berturut-turut adalah Kabupaten Tabanan (17.59 persen), Gianyar (17,13 persen) dan Buleleng (14,35 persen). Sedangkan jumlah rumah tangga rawan pangan terbesar berturutturut adalah kabupaten Buleleng (1,85 persen), Tabanan (1,39 persen) dan Gianyar (0,93 persen). Secara agregat dari ketiga kabupaten tersebut tingkat ketahanan pangan rumah tangga petani padi sawah berturut-turut adalah tahan pangan (49,07 persen, rentan pangan (37,97 persen), kurang pangan (8.79 persen) dan rawan pangan (4.17 persen). 


\section{KESIMPULAN DAN SARAN}

Sebanyak 58,33 persen rumah tangga petani padi sawah di Provinsi Bali memiliki pangsa pengeluaran pangan rendah dan 41,67 persen, rumah tangga memiliki pangsa pengeluaran tinggi. Secara agregat 86,57 persen rumah tangga petani cukup dalam mengkonsumsi energi dan 13,43 persenrumah tangga kurang mengkonsumsi energi. Tingkat ketahanan pangan rumah tangga petani berturut-turut 49,07 persen tahan pangan, 46,75 persen rentan/kurang pangan dan 4,16 persen rawan pangan.

Peningkatan pendapatan rumah tangga disertai dengan peningkatan pengetahuan dan penyadaran aspek pangan dan gizi diharapkan mampu meningkatkan akses rumah tangga terhadap pangan yang dibutuhkan. Mengingat sumberdaya yang dimiliki pemerintah relatif terbatas, maka partisipasi dan kepedulian seluruh komponen masyarakat diharapkan terlibat dalam upaya peningkatan ketahanan pangan rumah tangga.

\section{DAFTAR PUSTAKA}

Amaliyah, H dan S.M. Handayani.2011. Analisis Hubungan Proporsi Pengeluaran dan Konsumsi Pangan Dengan Ketahanan Pangan Rumah tangga Petani di Kabupaten Klaten. Jurnal SEPA 7 (2) $\therefore 110-118$.

Ariani, M dan H.P.S. Rachman. 2003. Analisis Tingkat Ketahanan Pangan Rumah Tangga. Media Gizi dan Keluarga 27 (2) : 1-6.

Darwanto, D.H. 2005. Ketahanan Pangan Berbasis Produksi dan Kesejahteraan Petani. Ilmu Pertanian 12 (2) : 152 164.

Ilham, N dan B. M. Sinaga. 2007. Penggunaan Pangsa Pengeluaran Pangan Sebagai Indikator Komposit Ketahanan Pangan. Jurnal SOCA 7 (3) : 213-328
Maxwell, S and T. Frankenberger. 1992. Household Food Security : Concepts, Indicators, and Measurements : a technical review. New York USA and Rome, UNICEF and IFAD.

Maxwell D, C Levin, M A Klemmeseau, M Rull, S Morris and C Aliadeke. 2000. Urban Livelihood and Food Nutrition Security in Greater Accra, Ghana. IFFRI in Collaborative with Noguchi Memmorial for Medical Research and WHO. Research Repport No. 112. Washington DC.

Purwaningsih, Y., S. Hartono., Masyhuri dan J.H. Mulyo.2010. Pola Pengeluaran Pangan Rumah Tangga Menurut Tingkat Ketahanan Pangan di Provinsi Jawa Tengah. Jurnal Ekonomi Pembangunan 11 (2) : 236-253.

Purwantini, T.B., H.P.S. Rachman dan Y Marisa. 2005. Analisis Ketahanan Pangan Regional dan Tingkat Rumah Tangga (Studi Kasus di Provinsi Sulawesi Utara) dalam Penguatan Ketahanan Pangan Rumah Tangga dan Wilayah Sebagai Basis Ketahanan Pangan Nasional. Monograph Series No.26. Pusat Analisis Sosial Ekonomi dan Kebijakan Pertanian. Bogor.

Rachman, H.P.S dan Mewa Ariani, 2002. Ketahanan Pangan : Konsep, Pengukuran dan Strategi. Forum Penelitian Agroekonomi (20):1

Tanziha, I dan E Herdiana. 2009. Analisis Jalur Faktor-faktor yang Mempengaruhi Tingkat Ketahanan Pangan di Kabupaten Lebak, Provinsi Banten. Jurnal Gizi dan Pangan 4 (2) : 106-115.

Usfar A. 2002. Household Coping Strategies for Food Security in Indonesia and Relation to Nutrition Status: Comparison Before and After the 1997 Economic Crisis. Sttutgart: Verlag Grauer, Beuren. 